\title{
DOES DIGITALIZATION AGGRANDIZE INCOME? THE INDONESIA FAMILY LIFE SURVEY FIFTH WAVE
}

\author{
Muhammad Kholisul Imam \\ Anas Tania Januari \\ Politeknik Negeri Malang1 \\ STAI Mahad Aly Al-Hikam² \\ kholisulimam@gmail.com
}

\author{
A R T I C L E I N F O \\ Article history: \\ Received : 2 December 2021 \\ Revised : 13 January 2021 \\ Accepted : 25 January 2022
}

Keywords:

Digitalization, Income, IFLS-5, Treatment Effect Model

DOI:

https://doi.org/10.33508/rima.v4i2.3547

\begin{abstract}
A B S T R A C T
The COVID-19 pandemic has shaken Indonesia's macroeconomy. The economic growth experienced a contraction accompanied by an increase in poverty and unemployment. On the other hand, the COVID-19 pandemic also provides an opportunity for the growth of the digital economy. Digitalization that goes well will increase economic activity due to greater accessibility. However, there has been a decline in income during the pandemic. Therefore, this research aims to learn whether digitalization can improve income levels by understanding the impact of having a cell phone and accessing the internet for economic activities towards revenues. Here, the treatment effect is conducted to estimate the magnitude of that impact and identify the factors determining digitalization (have a cell phone and access the internet for economic activities). This research uses secondary data obtained from the Indonesia family life survey fifth wave. The result shows that the income of someone who can digitize is higher than that of non-digitalization participants, indicating that digitalization significantly contributes to increased revenues. Moreover, object perception for having a cell phone and accessing the internet for economic activities supports people's interest in digitalization mainly due to happiness, subjective well-being, and marital status.
\end{abstract}

\section{INTRODUCTION}

The COVID-19 pandemic has shaken the Indonesian economy. Rubin (2011) states that a crisis originating from a health pandemic can have severe negative consequences for the economy, both on the supply and demand sides. BPS (2021a) released that the Indonesian economy in 2020 experienced a growth contraction of 2.07 percent compared to 2019. In addition, the COVID-19 pandemic also had implications for increasing poverty and unemployment. BPS (2021b) noted that the poverty rate in 2020 increased by 0.97 percent to 10.19 percent. At the same time, the number of poor people increased by 2.76 million people to 27.55 million people.
Meanwhile, on the employment aspect, BPS (2020) noted that the unemployment rate (TPT) in 2020 increased by 1.84 percentage points to 7.07 percent. The working population fell by 310,000 people to 128.45 million people. In the past year, underemployed and part-time workers rose by 3.77 percentage points and 3.42 percentage points, respectively. The sector that experienced the most significant decline was the Manufacturing Sector (1.30 percentage points). The COVID-19 pandemic has also made an increase in people working in informal activities by 4.59 percent. As of August 2021, more than 21 million people (approximately 10 percent of the working-age population) are affected by COVID-19 (BPS, 2021c). It consists of 
unemployment due to COVID-19 (1.82 million people), temporarily not working due to COVID-19 (1.39 million people), and working population who experienced a reduction in working hours due to COVID19 (17.41 million people).

Even though The COVID-19 pandemic has harmed the macroeconomy, this has encouraged the emergence of the digital economy phenomenon. In 2020 internet penetration is proliferating in Indonesia, from 47.69 percent in 2019 to 53.73 percent in 2020 (BPS, 2021d). The increase in internet penetration is in line with the increasing public need for online activities during the Covid19 pandemic.

With the rapid development of the digital economy, significant changes are taking place in social and economic life (Spence, 2021). A growing number of free digital goods and services are provided to consumers, linking sellers and buyers more efficiently. Digitalization can increase individual capacity and reduce costs. The improvement in these two components will have an impact on increasing income. However, the average Labor Wage in the last year showed a decline of 5.20 percent from 2.91 million to 2.76 million rupiahs (BPS, 2021c)

Therefore, this study aims to learn whether digitalization can improve income levels. The two objectives of this study are (i) to identify factors influencing access to the internet; and (ii) to estimate the impacts of digitalization on revenues.

\section{LITERATURE REVIEW}

\section{Capital ownership to welfare}

According to Todaro (2011), to achieve the expected livelihood goals, a person cultivates the various resources by taking advantage of existing opportunities.

Todaro (2011) categorizes livelihood assets into five groups called Pentagon Assets. Pentagon assets consist of human capital $(\mathrm{H})$ to education and skills, natural capital $(\mathrm{N})$ in the form of accessibility to natural resources such as land and water, financial capital (F) in the form of accessibility to finance, social capital (S) in the form of accessibility to social relations and work networks, and physical capital (P) in the form of accessibility to facilities and infrastructure.

The five components of assets have various relationships and interrelationships with each other. Access availability to capital also affects the process of formation and even changes in the structure of society. Furthermore, it affects household income and sustainability.

\section{Rational and irrational choice}

Choice theory is the theory behind selecting a person's decisions in every decision to be taken. The choice theory itself is divided into two classifications, namely rational choice, and irrational choice. The irrational choice is a person's choice in making a decision based on an irrational choice or usually a choice based on factors other than economic factors, such as taste, self-esteem, and satisfaction.

While rational choice is a person's decision based on economic factors such as how much profit a person will get in each of his activities, how much a person costs, and how much total income as a whole (Karbhari et al., 2018).

While Lester (2008) states that rational behavior is oriented to individual decisions, this paradigm is based on the neoclassical paradigm, which is based on the principle that human behavior always tries to maximize utility. Tversky \& Kahneman (1986) explain that rational choice theory will lead to a theory of decision-making viewed by rational choice theory to identify costs and benefits or the level of value and benefits. Therefore, the rational choice theory is closely related to decision-making theory.

A person's choice will be based on the expected level of profit. In the context of digitalization, it is the choice to be more open to new information and tools (the use of mobile phones and internet access for 
economic activities). Respondents who were originally closed-minded towards digital will change to using digitalization if they have higher income expectations. On the other hand, if the expectation of income due to digitization tends to be lower, of course, respondents will continue to use nondigitalization.

\section{The nexus between technology and revenue}

In economics, production is defined as obtaining or producing a good or service that begins with processing input factors and then produces output in the form of output (goods and services) that are valuable and useful for the needs of people's lives.

According to Fair (2007), production is a process to combine, transform, and convert inputs into outputs. From this definition, it is clear that to meet the needs; one must first carry out various production activities to produce an output, namely income.

All production activities can be referred to as factors of production. According to Mankiw (2008), factors of production are inputs used to produce outputs of goods and services. The two most important variables make up the factors of production, namely Capital (Capital) and Labor (Labor).

The production function shows the relationship between the number of products and the inputs used in the production process (Sukirno, 2009). The production level of a good depends on the amount of capital, the amount of labor, the amount of natural wealth, and the technology used. Production results show different amounts depending on the use of each factor of production can be formulated in general as follows::

$Q=f(K, L, R, T)$

$\mathrm{Q}$ is the output produced during a specific period; $\mathrm{K}$ is the capital; $\mathrm{L}$ is the number of workers; $\mathrm{R}$ is a resource; and $\mathrm{T}$ is technology.
Thus, the increasingly massive digitization, as a technology measure, is thought to encourage production. Consequently, the income earned will be even greater.

\section{Research Framework}

Based on the literature review, the relationship between digitization and income can be visualized as follows:

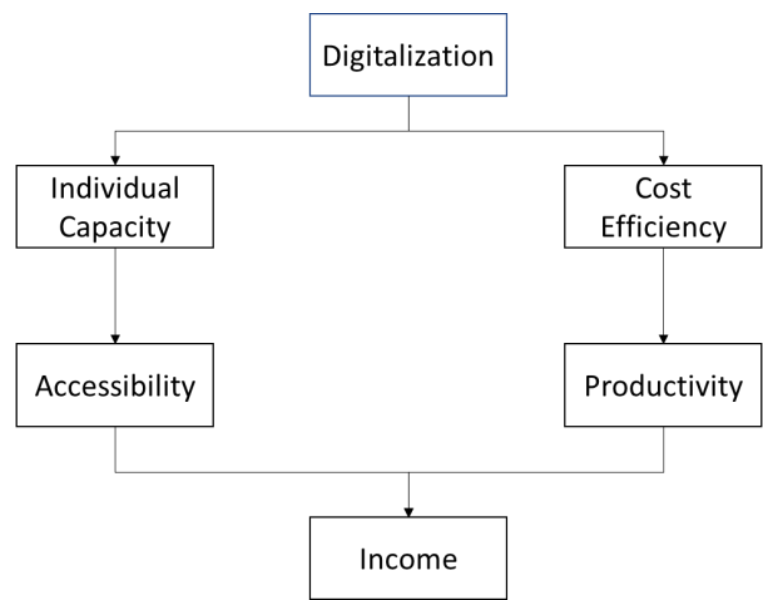

Figure 1: How digitalization increases the income level

Source: Extracted from various previous research

The relationship of digitization to increasing income can be viewed from two paths. First, increasingly massive digitization can increase individual capacity. Thus, accessibility to economic activity is getting bigger, and ultimately income is increasing. Second, faster digitization can reduce production and transactions costs, so higher productivity and more significant income increase.

\section{RESEARCH METHOD}

This research used the Indonesia family survey fifth wave. The number of observations is 831 respondents divided into two groups: (i) respondents efficiently do digitalization and (ii) non-digitalization respondents. In order to answer the research 
questions, the quantitative approach is used This research employs TEM (Treatment Effect Model) to explain the factors influencing respondent interest in digitalization and its impact on revenues. The Treatment Effect Model has two simultaneously estimated equations (Greene, 2012).

The first equation is applied to identify factors influencing the respondent's interest in digitalization, while the second equation is used to determine its role in revenue. The model specification is as follows:

$C_{i}=\gamma^{c} W_{i}^{c}+\mu c_{i}$ where $\mathrm{C}=1$ if participants easy access to digitalization and $C=0$ is otherwise................................ (Eq. 2) $Y_{i}=\beta^{c} X_{i}^{c}+\delta^{c} C_{i}+\varepsilon c_{i} \ldots \ldots \ldots \ldots \ldots$ (Eq. 3)

$\mathrm{C}$ is the respondent's decision to digitalize, where $C=1$ represents respondent participation, and $C=0$ is otherwise. $W$ is the factor influencing the interest of respondents to participate in digitalization. Factors include happiness, subjective wellbeing, and marital status. Moreover, $\mathrm{Y}$ is respondent revenues, while $X$ is the factor influencing respondent revenues, and $C$ is the decision of respondents to participate in digitalization. Specifically, the operational definition of variables can be seen in Appendix 1.

\section{RESULT AND DISCUSSION}

\section{Statistic result}

Based on the focus of this research, there are two research objectives. Both of these goals can be answered by using TEM. The treatment effect method aims to determine the average effect of the binary variable $(0 / 1)$ on the variable receiving the treatment (outcome variable) (Heckman, 1985). In the treatment effect model, it is assumed that there are two outcomes, namely, the variable that is treated as $\mathrm{y} 1$ and the other variable that is not treated as $\mathrm{y} 0$. Based on the TEM results, the factors that influence a person's decision to digitize can be seen in the following table.

Table 1. Identification Determinant of Digitalization Decision

\begin{tabular}{|l|c|c|c|}
\hline Digitalization Decision & Coeff. & S.E. & $\mathrm{P}>|\mathrm{z}|$ \\
\hline Marital Status & .4809 & .1621 & 0.003 \\
\hline Happiness & .7852 & .3024 & 0.009 \\
\hline Subjective well-being & .2835 & .1050 & 0.007 \\
\hline Constant & -2.274 & .3326 & 0.000 \\
\hline
\end{tabular}

Based on statistical results, the factors that influence a person's decision to digitize are (i) marital status, (ii) happiness, and (iii) perspective on the condition of the respondent's wealth.

Marital status has a coefficient value of 0.4809 with a significance value of 0.003 . This figure shows that the coefficient value is believed not to be zero with a confidence level of $99 \%$. The coefficient value of 0.4809 indicates that assuming other variables are constant, married people tend to digitize with a $48 \%$ greater tendency than those not married.

Happiness has a coefficient value of 0.7852 with a significance value of 0.009 . The coefficient value is believed not to be zero with a confidence level of $99 \%$. The coefficient value of 0.7852 indicates that someone happy tends to digitize with a tendency of $78 \%$ greater than someone who is not happy, cateris paribus.

Perspective on the respondent's wealth condition has a coefficient value of 0.2835 with a significance value of 0.007 . Thus, the coefficient value is believed not to be zero with a confidence level of $99 \%$. The coefficient value of 0.2835 indicates that assuming other variables are constant, someone who feels rich tends to digitize with a $28 \%$ greater tendency than someone who feels not rich.

Constants with a negative and significant sign indicate that respondents tend to choose not to digitize when all variables are zero. 
Meanwhile, the second equation of the treatment effect model can be seen from the following table.

Table 2. Impact of Digitalization on Revenue

\begin{tabular}{|l|c|c|c|}
\hline \multicolumn{1}{|c|}{ Revenue } & Coeff. & S.E. & $P>|z|$ \\
\hline Age & 3853.1 & 4091.7 & 0.346 \\
\hline Higher Education & 673989.7 & 181434.1 & 0.000 \\
\hline Male & 1033598 & 171611.2 & 0.000 \\
\hline $\begin{array}{l}\text { Actively } \\
\text { participate in } \\
\text { economic activity }\end{array}$ & -47654.5 & 139254.7 & 0.732 \\
\hline Digitalization & 1827762 & 282647.2 & 0.000 \\
\hline Constant & 130446.7 & 211973.3 & 0.538 \\
\hline
\end{tabular}

Based on statistical results, income variables are higher education, male gender, and digitalization. In contrast, the variables that do not impact income are age and being active in participating in community economic activities. The two variables have a significance level of more than $5 \%$, namely 0.34 and 0.73 . Thus, the coefficient value of the age variable and the active variable in participating in community economic activities is more believed to be zero with $34 \%$ and $73 \%$ confidence levels. Thus, both age and active participation in community economic activities do not affect income.

Higher education has a coefficient value of 673,989 with an error rate of less than $1 \%$. The coefficient value is believed to be not equal to zero by more than $99 \%$. The coefficient value shows that people who have the last education in higher education, namely diploma/college, have a higher income of 673,989 rupiahs than those who are not highly educated, assuming other variables are constant.

Male has a coefficient value of $1,033,598$ with an error rate of less than $1 \%$. The coefficient value is believed to be not equal to zero by more than $99 \%$. The coefficient value shows that male people have a higher income of 1,033,598 rupiahs than those who are not men, assuming that other variables are constant.

Digitalization has a coefficient value of $1,827,762$ with an error rate of less than $1 \%$. The coefficient value is believed to be not equal to zero by more than $99 \%$. The coefficient value shows that people who do digitization, having a cellphone and accessing the internet for economic activities, have a higher income of 1,827,762 rupiahs than those who do not digitize, assuming other variables are constant.

The constant has a significance value of 0.538 , which is above $5 \%$. This figure shows that the null hypothesis that the constant value is zero is accepted.

\section{Determinants of digitalization decision}

Based on table 1, marital status, happiness, and subjective well-being encourage someone to choose digitalization.

Married people tend to choose to digitize because they expect increasing income. Married people are required to have a significant income to meet the increasing needs. The digitization that cuts transaction costs makes workers more productive. Thus, income will increase.

Meanwhile, the other two factors, namely happiness and subjective well-being implement irrational choices. The size that is considered is no longer about profit and loss. Someone who is happy and thinks rich tends to digitize, not earn a higher income. The cause of digitizing is driven more by non-material factors, such as the surrounding environment that has digitized and demands of work.

\section{Determinants of revenue}

Based on Table 2, factors that affect income other than digitization are education and gender. Meanwhile, age and activity in community economic organizations have no impact on income

Higher education reflects individual capacities. The higher the education one takes, the more mature the hard and soft skills ability. This condition differentiates them from non-graduates of higher education. In addition, higher education also reflects insights in managing their resources more effectively. Thus, the returns 
from the factors of production owned will be greater. This result is in line with the theory that higher education has a positive impact on education. Based on the results of the Sakernas 2020, the average wage for workers with university education is 4.24 million rupiahs, while workers with elementary school education and below are 1.65 million rupiahs (BPS, 2020).

Gender reflects the productivity component. Men have higher incomes than women because men do not have factors that prevent them from working periodically. Meanwhile, women have monthly cycles and even become pregnant, requiring them to reduce their work activities periodically. Naturally, the productivity of men is greater than that of women. In comparison, the theory states that productivity has a positive effect on income. Based on the results of the Sakernas 2020, the income of men is about 600 thousand rupiahs greater than the income earned by women (BPS, 2020).

Age has no impact on income, indicating no significant difference in income between the elderly and young people. Age reflects a person's experience in work. The older a person is, the more experience they have. Much experience and mature causes work better and more efficiently so that income will increase. However, the results show that age has no impact on income. This condition shows that although the young population has relatively minimal work experience, their income is not significantly different from that of the older population. Usually, this condition is caused by the innovation factor that young people can do better. Innovation causes production to be more efficient so that income will be even higher.

Being active in participating in community economic organizations has no impact on income. Participating in economic activity reflects social capital where the theory states that higher social capital can encourage an increase in income.
There are three functions of community economic activities, namely: (i) loan or saving; (ii) production; and (iii) expanding the market, with each type of cooperatives giving different benefits to their participants. The saving or loan community economic activities will contribute to financial accessibility. In contrast, the production community economic activities will contribute to providing raw materials and helping the production process, while the consumer community economic activities will mainly contribute to marketing and selling.

Many communities' economic activities do not profit as their primary objective because they work based on service at a cost (Sitio \& Tamba, 2001). Participants join a community economic activity to meet their everyday economic, social, and cultural needs (Suprapto et al., 2020). Thus, there is a possibility that participating in community economic activities will not increase income.

Digitalization and Income: Investigation Result

Digitization has a positive impact on revenue. People who digitize have higher incomes than those who do not. There are two reasons why digitalization can increase income: (i) increasing individual capacity; and (ii) reducing transaction costs.

The increasingly massive digitalization causes the individual's insight to be broader due to expanding access to information. Information is getting easier to reach a relatively low cost. The implication is that individuals can manage resources more efficiently. The perfect information also causes the uncertainty to decrease. Less uncertainty can save unnecessary costs. So, in the end, the income will increase.

In addition, growing digitization has resulted in lower transaction costs. For consumers, lower transaction costs encourage more economic transactions. Meanwhile, for producers, lower transaction costs encourage business competitiveness (Suprapto et al., 2020). Thus, the income will increase. 


\section{CONCLUSIONS}

Based on this research, the policy of digitalization is on the right track. The conclusions are withdrawn from this research finding, which are:

Firstly, digitalization significantly improves income if the participant can improve access to information and reduce transaction costs.

Secondly, the reason someone chooses digitization is more significant due to irrational reasons. The level of happiness plays a vital role as a determinant of someone doing digitization.

Future studies should calculate the index of inclusive growth, which considered economic development, income inequality, poverty, and unemployment. It should also use dummy locations to examine feature differences between regions. This study is recommended as a reference to achieve a more comprehensive understanding, based on the impact of government debt on economic growth and income inequality.

\section{REFERENCE}

BPS. (2021a, February 5). Ekonomi Indonesia 2020 Turun sebesar 2,07 Persen (c-to-c). Berita Resmi Statistik. https://www.bps.go.id/pressrelease/ 2021/02/05/1811/ekonomi-indonesia2020-turun-sebesar-2-07-persen--c-toc-.html

BPS. (2021b, February 15). Persentase Penduduk Miskin September 2020 naik menjadi 10,19 persen. Berita Resmi Statistik.

https://www.bps.go.id/pressrelease/ 2021/02/15/1851/persentasependuduk-miskin-september-2020naik-menjadi-10-19-persen.html

BPS. (2021c, November 5). [REVISI per 09/11/2021] Agustus 2021: Tingkat Pengangguran Terbuka (TPT) sebesar 6,49 persen. Berita Resmi Statistik. https://www.bps.go.id/pressrelease/ 2021/11/05/1816/-revisi-per-09-112021--agustus-2021--tingkat- pengangguran-terbuka--tpt--sebesar-649-persen.html

BPS. (2021d). Indeks Pembangunan Teknologi Informasi dan Komunikasi 2020. Jakarta: BPS Indonesia.

BPS. (2020, November 5). [REVISI per 18/02/2021] Agustus 2020: Tingkat Pengangguran Terbuka (TPT) sebesar 7,07 persen. Berita Resmi Statistik. https://www.bps.go.id/pressrelease/ 2020/11/05/1673/agustus-2020-tingkat-pengangguran-terbuka--tpt-sebesar-7-07-persen.html

Case, Karl. (2007). Case Fair: Prinsip-prinsip Ekonomi Jilid 2. Jakarta: Erlangga.

Greene. R. (2012). Econometric Analysis, 7th Edition. New York. Pearson.

Heckman, J., \& Robb, R. (1985), Alternative methods for evaluating the impact of interventions: An overview, Journal of Econometrics, 30, (1-2), 239-267.

Karbhari, Y., Muye, I., Hassan, A. F. S., \& Elnahass, M. (2018). Governance mechanisms and efficiency: Evidence from an alternative insurance (Takaful) market. Journal of International Financial Markets, Institutions and Money, 56, 7192.

Lester, Bijou. (2011). An exploratory analysis of composite choices: Weighing rationality versus irrationality. Journal of Socio-economics. 40. 949-958.

Mankiw, Gregory. (2008). Principles of Economics 5th edition. Ohio: SouthWestern Cengage Learning.

Rubin, H. (2011). Future Global Shocks: Pandemics. Paris: OECD.

Sitio, A., \& Tamba, H. (2001). Koperasi: Teori dan Praktek. Jakarta: Erlangga

Spence, Michael. (2021). Government and economics in the digital economy. Journal of Government and Economics, 3, 100020.

Sukirno, Sadono. (2009). Mikro Ekonomi Teori Pengantar Edisi Ketiga. Jakarta: Rajawali Pers.

Suprapto, E., Santoso, D.B., Imam, M.K., \& Paksi, G.M. (2020). Does cooperative participant strengthen 
small and medium enterprises competitiveness in East Java? International Journal of Project Organisation and Management, 12(2), 178-189.
Todaro, M. P. and Smith, S. C. (2011) Pembangunan Ekonomi Jilid 1 Edisi 11. Jakarta: Erlangga.

Tversky, A., \& Kahneman, D. (1986). Rational Choice and the Framing of Decisions. The Journal of Business, 59(4), S251-S278. 


\section{Appendix 1. Operational definition}

\begin{tabular}{|c|c|c|c|}
\hline Variable & Concept & Definition & Source IFLS-5 \\
\hline Income & Welfare & Wages earned from work & $\begin{array}{l}\text { Book 3A Section } \\
\text { TK1 Variable } \\
\text { TK16A }\end{array}$ \\
\hline Digitization & $\begin{array}{l}\text { Accessibility and } \\
\text { Technology }\end{array}$ & $\begin{array}{l}\text { Individuals who have mobile phones and } \\
\text { are able to access the internet }\end{array}$ & $\begin{array}{l}\text { Book 3A Section } \\
\text { DL1 Variable } \\
\text { DL03B and DL03D }\end{array}$ \\
\hline Higher education & Human Capital & $\begin{array}{l}\text { Dummy variables: } \\
1 \text { is the highest education that has been / is } \\
\text { being attended is a diploma academy and } \\
\text { university and } 0 \text { is not a higher education }\end{array}$ & $\begin{array}{l}\text { Book 3A Section } \\
\text { DL1 Variable DL06 }\end{array}$ \\
\hline Age & & Current age & $\begin{array}{l}\text { Book 3A Section } \\
\text { Cov Variable age }\end{array}$ \\
\hline Male & Pnystcal Capital & $\begin{array}{l}\text { Dummy variables: } \\
1 \text { is male and } 0 \text { is not male }\end{array}$ & $\begin{array}{l}\text { Book 3A Section } \\
\text { Cov Variable sex }\end{array}$ \\
\hline $\begin{array}{l}\text { Actively participate } \\
\text { in community } \\
\text { economic activities }\end{array}$ & Social Capital & $\begin{array}{l}\text { Dummy variables: } \\
1 \text { is to actively participate in community } \\
\text { economic activities such as cooperatives, } \\
\text { village/ kelurahan savings and loans, } \\
\text { healthy funds, PNPM } \\
0 \text { is not actively participating in } \\
\text { community economic activities }\end{array}$ & $\begin{array}{l}\text { Book 3B Section } \\
\text { PM2 Variable } \\
\text { PM3TYPE and } \\
\text { PM16 }\end{array}$ \\
\hline Marital Status & & $\begin{array}{l}\text { Dummy variables: } \\
1 \text { is married status and } 0 \text { is non-married } \\
\text { status }\end{array}$ & $\begin{array}{l}\text { Book 3A Section } \\
\text { Cov Variable } \\
\text { marstat }\end{array}$ \\
\hline Happiness & Perception of & $\begin{array}{l}\text { Dummy variables: } \\
1 \text { is happy and } 0 \text { is unhappy }\end{array}$ & $\begin{array}{l}\text { Book 3A Section } \\
\text { SW Variable SW12 }\end{array}$ \\
\hline Subjective Wealthy & & $\begin{array}{l}\text { Dummy variables: } \\
1 \text { is feeling rich and } 0 \text { is feeling not rich }\end{array}$ & $\begin{array}{l}\text { Book 3A Section } \\
\text { SW Variable SW01 }\end{array}$ \\
\hline
\end{tabular}




\section{Appendix 2.}

Do File in Stata

/ / Book 3a section SW

gen kaya $=1$ if $\mathrm{sw} 01==6$

replace kaya $=1$ if $\mathrm{sw} 01==5$

replace kaya $=1$ if $\mathrm{sw} 01==4$

replace kaya $=0$ if $\mathrm{sw} 01==3$

replace kaya $=0$ if sw01 $==2$

replace kaya $=0$ if $\mathrm{sw} 01==1$

tab kaya

gen bahagia $=1$ if $\operatorname{sw} 12==1$

replace bahagia $=1$ if $\mathrm{sw} 12==2$

replace bahagia $=0$ if $\operatorname{sw} 12==3$

replace bahagia $=0$ if $\mathrm{sw} 12==4$

tab bahagia

keep pidlink kaya bahagia

sort pidlink

save

file E: $\backslash P R O J U R N A L \backslash 6$ RIMA UNIKA WIDYA MANDALA \praktek 241121 \kaya bahagia.dta saved

/ / Book 3a Section dl1

gen internet $=1$ if $\mathrm{d} 103 \mathrm{~d}==1$

replace internet $=0$ if $\mathrm{dl03d}==3$

tab internet

gen ponsel $=1$ if $\mathrm{dl03b}==1$

replace ponsel $=0$ if $\mathrm{dl} 103 \mathrm{~b}==3$

tab ponsel

gen digital $=1$ if ponsel= $=1$

replace digital $=0$ if ponsel $=0$

replace digital $=1$ if internet $==1$

replace digital $=0$ if internet $==0$

tab digital

gen pendtinggi $=($ inlist $(\mathrm{d} 106,60,61,62,63))$

tab pendtinggi

keep pidlink internet ponsel digital pendtinggi

sort pidlink

save

file E: \PRO JURNAL $\backslash 6$ RIMA UNIKA WIDYA MANDALA \praktek 241121 internet ponsel digital pendtinggi.dta saved

//Book 3a Section dl1

gen internet $=1$ if $\mathrm{d} l 03 \mathrm{~d}==1$

replace internet $=0$ if $\mathrm{d} 103 \mathrm{~d}==3$

tab internet

gen pendtinggi $=($ inlist $(\mathrm{d} 106,60,61,62,63))$

tab pendtinggi

keep pidlink internet pendtinggi

sort pidlink

save

file E: \PRO JURNAL \6 RIMA UNIKA WIDYA MANDALA \praktek 241121 \internet pendtinggi.dta saved

/ / Book 3a Section COV

gen laki=1 if $\operatorname{sex}==1$

replace laki $=0$ if $\operatorname{sex}==3$

tab laki

gen menikah $=1$ if marstat $==2$

replace menikah $=0$ if marstat $==1$

replace menikah $=0$ if marstat $==3$

replace menikah $=0$ if marstat $==4$

replace menikah $=0$ if marstat $==5$ 
replace menikah $=0$ if marstat $==6$

tab menikah

keep pidlink menikah laki age

sort pidlink

save

file E: \PRO JURNAL $\ 6$ RIMA UNIKA WIDYA MANDALA \praktek 241121 \cov.dta saved

/ / Book 3b Section pm2

gen programekonomi=(inlist(pm3type,"B","Q","R","R1"))

tab programekonomi

keep if programekonomi $==1$

gen partisipasi $=(\operatorname{inlist}(\mathrm{pm} 16,1))$

tab partisipasi

duplicates report hhid14 pid14

collapse (sum) partisipasi, by(pidlink)

tab partisipasi

gen aktif $=1$ if partisipasi $==4$

replace aktif $=1$ if partisipasi $==3$

replace aktif $=1$ if partisipasi $==2$

replace aktif $=1$ if partisipasi $==1$

replace aktif $=0$ if partisipasi $=0$

tab aktif

keep pidlink aktif

sort pidlink

save

file E: \PRO JURNAL 6 RIMA UNIKA WIDYA MANDALA \praktek 241121 \aktif.dta saved

//Book 3a Section TK1

gen lupah=ln(tk16a)

keep pidlink lupah

sort pidlink

merge pidlink using "E: \PRO JURNAL $\backslash 6$ RIMA UNIKA WIDYA MANDALA \praktek 241121 \kaya bahagia.dta" tab_merge

sort pidlink

drop_merge

merge pidlink using "E: \PRO JURNAL \6 RIMA UNIKA WIDYA MANDALA \praktek 241121 \cov.dta"

tab_merge

sort pidlink

drop_merge

merge pidlink using "E: \PRO JURNAL \6 RIMA UNIKA WIDYA MANDALA \praktek 241121 \aktif.dta"

tab_merge

sort pidlink

drop_merge

merge pidlink using "E: $\backslash P R O J U R N A L \backslash 6$ RIMA UNIKA WIDYA MANDALA \praktek $241121 \backslash$ internet ponsel digital pendtinggi.dta"

tab_merge

sort pidlink

drop_merge

merge pidlink using "E: \PRO JURNAL \6 RIMA UNIKA WIDYA MANDALA \praktek 241121 \ketaatan.dta"

tab_merge

sort pidlink

drop_merge

treatreg lupah age pendtinggi laki aktif, treat (digital= menikah bahagia kaya) 


\section{Appendix 3. Statistical result}

\begin{tabular}{|c|c|c|c|c|c|c|}
\hline Iteration 0: & $\log$ likeliho & $o d=-13389$ & .738 & & & \\
\hline Iteration 1: & log likeliho & $o d=-13333$ & .594 & & & \\
\hline Iteration 2: & $\log$ likeliho & $o d=-13326$ & .559 & & & \\
\hline Iteration 3: & $\log$ likeliho & $o d=-1332$ & 6.35 & & & \\
\hline Iteration 4: & $\log$ likeliho & $o d=-1332$ & 6.35 & & & \\
\hline Treatment-effect & ts model -- & MLE & & Number & f obs & $\begin{array}{r}831 \\
\end{array}$ \\
\hline Log likelihood $=$ & $=-13326.35$ & & & $\begin{array}{l}\text { Wald } \\
\text { Prob }>\end{array}$ & $\begin{array}{l}2(5) \\
\text { hi2 }\end{array}$ & $\begin{array}{l}140.97 \\
0.0000\end{array}$ \\
\hline I & Coef. & Std. Err. & z & $P>|z|$ & [95응 Conf. & Interval ] \\
\hline upah & & & & & & \\
\hline age I & 3853.167 & 4091.721 & 0.94 & 0.346 & -4166.46 & 11872.79 \\
\hline pendtinggi | & 673989.7 & 181434.1 & 3.71 & 0.000 & 318385.4 & 1029594 \\
\hline laki | & 1033598 & 171611.2 & 6.02 & 0.000 & 697246.2 & 1369950 \\
\hline aktif | & -47654.58 & 139254.7 & -0.34 & 0.732 & -320588.8 & 225279.7 \\
\hline digital | & 1827762 & 282647.2 & 6.47 & 0.000 & 1273783 & 2381740 \\
\hline _cons I & 130446.7 & 211973.3 & 0.62 & 0.538 & -285013.3 & 545906.7 \\
\hline digital | & & & & & & \\
\hline menikah । & .4809475 & .162194 & 2.97 & 0.003 & .1630532 & .7988418 \\
\hline bahagia | & .7852138 & .3024468 & 2.60 & 0.009 & .192429 & 1.377999 \\
\hline kaya I & .2835201 & .1050945 & 2.70 & 0.007 & .0775388 & .4895015 \\
\hline _cons I & -2.274937 & .3326847 & -6.84 & 0.000 & -2.926987 & -1.622887 \\
\hline /athrho | & -.5418046 & .1039716 & -5.21 & 0.000 & -.7455851 & -.3380241 \\
\hline /Insigma | & 14.276 & .0304236 & 469.24 & 0.000 & 14.21637 & 14.33563 \\
\hline rho | & -.4943528 & .0785625 & & & -.6325077 & -.3257123 \\
\hline sigma | & 1584847 & 48216.81 & & & 1493106 & 1682225 \\
\hline lambda | & -783473.6 & 139934.9 & & & -1057741 & -509206.3 \\
\hline
\end{tabular}

